\title{
EFFECT OF ANTI-RETROVIRAL THERAPY (ART) ON HEARING IN HIV POSITIVE PATIENTS
}

\author{
Swathi V. M11, Satish S. Raju², Leela Tejaswini ${ }^{3}$, Praveen Kumar B. Y4, M. K. Veenapani' ${ }^{5}$ S. N. Manjunath ${ }^{6}$
}

${ }^{1}$ Audiologist, Department of ENT, Mysore Medical College \& Research Institute, Mysore.

${ }^{2}$ Associate Professor, Department of ENT, Mysore Medical College \& Research Institute, Mysore.

${ }^{3}$ Senior Resident, Department of ENT, Mysore Medical College \& Research Institute, Mysore.

${ }^{4}$ Associate Professor, Department of ENT, Mysore Medical College \& Research Institute, Mysore.

5 Professor and HOD, Department of ENT, Mysore Medical College \& Research Institute, Mysore.

${ }^{6}$ Associate Professor, Department of PSM, Mysore Medical College \& Research Institute, Mysore.

\begin{abstract}
BACKGROUND

Not long ago, HIV was an infection which used to be a progressive, advancing and incurable illness with no effective treatment and leading to fast deterioration in health resulting in death. The advent of ART (Anti-Retroviral Treatment) has made a remarkable effect on the management, as HIV/AIDS are living longer and this often means living with ailments that include auditory dysfunction. This study was done to know the effect of ART on hearing in HIV positive patients.
\end{abstract}

\section{OBJECTIVES}

To study the effect of ART on hearing in HIV positive patients by using Pure Tone and High Frequency Audiometry and OtoAcoustic Emission.

\section{STUDY AND DESIGN}

Longitudinal study with the study population being HIV positive patients registered at ART Centre at K.R. Hospital, Mysore, from Jan 2013 to Jan 2015.

\section{MATERIALS AND METHODS}

Patients with HIV whose CD4 $<350$ cells $/ \mathrm{mm}^{3}$ and newly started with ART were recruited. After a detailed case history and treatment history, a thorough general physical examination was done. Ear examination and Otomicroscopy was carried out. Hearing was assessed using Pure Tone and High Frequency Audiometry up to $12 \mathrm{KHz}$ and Oto-Acoustic Emissions up to $6 \mathrm{KHz}$ at the time of initiation of ART (baseline), $3^{\text {rd }}$ month and $9^{\text {th }}$ month.

\section{RESULTS}

In our study, the patients were in the age group of 25 to 45 years and males constituted $70 \%$ and females $30 \%$. Transient Evoked Oto-Acoustic Emissions (Screener), which was done at the time of initiation of ART (Baseline) on all the 40 HIV positive patients had normal OAE's. During the $3^{\text {rd }}$ and $9^{\text {th }}$ month, OAE's in the frequency range from $1500 \mathrm{~Hz}$ to $6000 \mathrm{~Hz}$ were affected in some patients. Hearing assessment using Pure Tone and High Frequency Audiometry up to $12 \mathrm{kHz}$ were done and Mean and Standard Deviation were calculated and the p-values were significant in the frequency range from $3000 \mathrm{~Hz}$ to $12000 \mathrm{~Hz}$.

\section{CONCLUSION}

HIV positive patients had abnormal OAE's in higher frequencies as the duration of ART increases. P-values were significant in higher frequencies with pure tone and high frequency audiometry as the duration of ART increases in HIV positive patients.

\section{KEYWORDS}

ART (Anti-Retroviral Treatment), HIV Patients, Pure Tone and High Frequency Audiometry, Oto-acoustic Emission.

\begin{abstract}
HOW TO CITE THIS ARTICLE: Swathi VM, Raju SS, Tejaswini L, et al. Effect of anti-retroviral therapy (ART) on hearing in HIV positive patients. J. Evolution Med. Dent. Sci. 2016;5(41):2528-2530, DOI: 10.14260/jemds/2016/590

\section{INTRODUCTION}

Not long ago, HIV was an infection which used to be a progressive, advancing and incurable illness with no effective treatment and leading to fast deterioration in health, resulting in death. The initiation of Anti-Retroviral Therapy (ART) has made the management of HIV infected patients remarkable in

this often means dealing with impairments, which include auditory dysfunction as a result of opportunistic infections or treatment with drug combinations that are potentially ototoxic. There is paucity of literature and knowledge base in this regard and the present study is done with the aim to find the effect of ART on hearing in HIV positive patients.
\end{abstract} the recent past. HIV positive patients are living longer now and

Financial or Other, Competing Interest: None.

Submission 02-04-2016, Peer Review 28-04-2016,

Acceptance 03-05-2016, Published 21-05-2016.

Corresponding Author:

Dr. Satish S. Raju

\#1707, 6 ${ }^{\text {th }}$ Main,

Vijayanagar II ${ }^{\text {nd }}$ Stage,

Mysore-17.

E-mail: entssr@yahoo.com

DOI: $10.14260 /$ jemds $/ 2016 / 590$

\section{OBJECTIVES}

To study the effect of ART on hearing in HIV positive patients by using Pure Tone and High Frequency Audiometry and OtoAcoustic Emission.

\section{STUDY AND DESIGN}

Study Population

HIV positive patients registered at ART Centre at K.R. Hospital, Mysore. 


\section{Study Design}

Longitudinal Study.

\section{Sample Size}

It was calculated with 5\% Alpha error and $80 \%$ Power. Considering the prevalence of HIV as $0.7 \%$ in general population, the sample size was found to be 40 .

\section{Study Period}

From Jan. 2013 to Jan. 2015

\section{MATERIALS AND METHODS}

Written informed consent was taken from the study population. Newly registered cases at ART centre were recruited for the study. After a detailed case history and treatment history, a thorough general physical examination was done. Ear examination and Otomicroscopy was carried out. Patient's willingness to undergo investigations was confirmed. Hearing was assessed using Pure Tone and High Frequency Audiometry up to $12 \mathrm{KHz}$ and Oto-Acoustic Emissions up to $6 \mathrm{KHz}$ at the time of initiation of ART (Baseline), $3^{\text {rd }}$ month and $9^{\text {th }}$ month. Those patients who had a CD4 count less than 350 cells $/ \mathrm{mm}^{3}$ were started with first line combination ART drug regimen after the baseline hearing assessment. New recruits were taken for those who dropped out midway (12 patients). Patients were selected based on the following inclusion and exclusion criteria.

\section{Inclusion Criteria}

- Age between 25 to 45 years.

- Patients with HIV whose CD4 $<350$ cells $/ \mathrm{mm}^{3}$ and newly started with ART were recruited.

\section{Exclusion Criteria}

- Any past or present history of middle ear infection or on any ototoxic drugs.

- Any past or present history of ear surgery or ear trauma or noise exposure.

- Presbycusis.

- Hereditary causes of deafness.

\section{Statistical Methods}

SPSS 16 version was used for the analysis of the data. Descriptive statistics like Mean and Standard Deviation were used. T test and ANOVA test were used for analysis of the data.

\section{RESULTS}

During the study period from Jan 2013 to Jan 2015 of the 40 HIV positive patients, males constituted $28(70 \%)$ and females constituted $12(30 \%)$. In our study, the patients were in the age group of 25 to 45 years with a mean age of 32.5 years +/7.5 years as shown in Table I.

\begin{tabular}{|c|c|}
\hline Male & $70 \%$ \\
\hline Female & $30 \%$ \\
\hline Mean Age & 32.5 years $+/-7.5$ \\
\hline Table I: Distribution According to Gender and Mean Age \\
\hline
\end{tabular}

OTO- Acoustic Emission

\begin{tabular}{|c|c|c|c|c|c|c|}
\hline $\begin{array}{c}\text { Month/ } \\
\text { Frequency }\end{array}$ & $\begin{array}{c}\text { I Month } \\
\text { (Number } \\
\text { 40) } \\
\text { Normal } \\
\text { Affected }\end{array}$ & $\begin{array}{c}\text { III Month } \\
\text { (Number }= \\
\text { 40) } \\
\text { Normal } \\
\text { Affected }\end{array}$ & $\begin{array}{c}\text { IX Month } \\
\text { (Number }= \\
\text { 40) } \\
\text { Normal } \\
\text { Affected }\end{array}$ \\
\hline $250 \mathrm{~Hz}$. & 40 & 0 & 40 & 0 & 40 & 0 \\
\hline $500 \mathrm{~Hz}$. & 40 & 0 & 40 & 0 & 40 & 0 \\
\hline $1000 \mathrm{~Hz}$. & 40 & 0 & 40 & 0 & 40 & 0 \\
\hline $1500 \mathrm{~Hz}$. & 40 & 0 & 4 & 36 & 1 & 39 \\
\hline $2000 \mathrm{~Hz}$. & 40 & 0 & 3 & 37 & 0 & 40 \\
\hline $3000 \mathrm{~Hz}$. & 40 & 0 & 3 & 37 & 0 & 40 \\
\hline $4000 \mathrm{~Hz}$. & 40 & 0 & 2 & 38 & 0 & 40 \\
\hline $6000 \mathrm{~Hz}$. & 40 & 0 & 1 & 39 & 0 & 40 \\
\hline \multicolumn{7}{|c|}{ Table II: Distribution According to Month and } \\
Frequency \\
of Normal and Affected \\
\hline
\end{tabular}

In our study, Transient Evoked Oto-Acoustic Emissions (Screener) was done in all the $40 \mathrm{HIV}$ positive patients up to 6 $\mathrm{KHz}$ at the time of initiation of ART (Baseline), $3^{\text {rd }}$ month and $9^{\text {th }}$ month. At the time of initiation of ART (Baseline), all the 40 HIV positive patients had normal OAE's. During the $3^{\text {rd }}$ and $9^{\text {th }}$ month, OAE's in the frequency range from $1500 \mathrm{~Hz}$ to $6000 \mathrm{~Hz}$ were affected in some patients as shown in Table II.

\section{Pure Tone and High Frequency Audiometry}

\begin{tabular}{|c|c|c|c|c|c|c|c|}
\hline $\begin{array}{c}\text { Month/ } \\
\text { Frequency }\end{array}$ & \multicolumn{2}{|c|}{$\begin{array}{c}\text { I Month } \\
\text { (Number } \\
\text { 40) } \\
\text { Mean SD }\end{array}$} & \multicolumn{2}{c|}{$\begin{array}{c}\text { III Month } \\
\text { (Number }=\end{array}$} & \multicolumn{2}{c|}{$\begin{array}{c}\text { IX Month } \\
\text { Mean SD }\end{array}$} & \multicolumn{2}{c|}{$\begin{array}{c}\text { 40) } \\
\text { Mean SD }\end{array}$} & $\begin{array}{c}\text { p- } \\
\text { Value }\end{array}$ \\
\hline $250 \mathrm{~Hz}$. & 17.88 & 4.06 & 18.12 & 3.70 & 18.50 & 3.43 & 0.11 \\
\hline $500 \mathrm{~Hz}$. & 17.88 & 2.97 & 18.25 & 3.31 & 19.63 & 3.65 & 0.12 \\
\hline $1000 \mathrm{~Hz}$. & 18.75 & 2.94 & 19.38 & 3.04 & 19.38 & 3.04 & 0.31 \\
\hline $1500 \mathrm{~Hz}$. & 18.75 & 3.88 & 18.75 & 3.88 & 19.75 & 4.08 & 0.33 \\
\hline $2000 \mathrm{~Hz}$. & 20.13 & 3.67 & 20.38 & 3.47 & 20.38 & 3.47 & 0.37 \\
\hline $3000 \mathrm{~Hz}$. & 19.38 & 3.04 & 19.38 & 3.04 & 22.88 & 3.74 & $0.00^{*}$ \\
\hline $4000 \mathrm{~Hz}$. & 20.00 & 3.58 & 24.50 & 4.50 & 28.50 & 4.27 & $0.00^{*}$ \\
\hline $6000 \mathrm{~Hz}$. & 17.88 & 4.22 & 26.25 & 3.71 & 29.00 & 3.79 & $0.00^{*}$ \\
\hline $8000 \mathrm{~Hz}$. & 19.25 & 3.11 & 29.00 & 3.79 & 33.00 & 5.29 & $0.00^{*}$ \\
\hline $10000 \mathrm{~Hz}$. & 19.00 & 3.43 & 33.38 & 4.44 & 36.75 & 5.26 & $0.00^{*}$ \\
\hline $12000 \mathrm{~Hz}$. & 20.00 & 3.20 & 39.25 & 4.61 & 43.38 & 7.02 & $0.00^{*}$ \\
\hline
\end{tabular}

Table III: Distribution According to Month and Frequency of Normal and Affected

\section{*--- Significant}

Hearing assessment using Pure Tone and High Frequency Audiometry up to $12 \mathrm{kHz}$ were done in all the $40 \mathrm{HIV}$ positive patients at the time of initiation of ART (baseline), $3^{\text {rd }}$ month and $9^{\text {th }}$ month. Mean and Standard Deviation were calculated and the $\mathrm{p}$-values were significant in the frequency range from $3000 \mathrm{~Hz}$ to $12000 \mathrm{~Hz}$ as shown in Table III.

\section{DISCUSSION}

Living longer with HIV often means dealing with impairments, activity limitations and participation restrictions that range from moderate or inconvenient to severe and debilitating disease, which is one of the more important determinants of health-related quality of life in person with HIV/AIDS.(1)

However, as a result of recent advances in ART the focus of therapy has shifted to a more rehabilitative approach with the emphasis on enhancing quality of life.(2) 
National Institute of Health (NIH) estimates indicate that as many as 75 percent of adults with AIDS experience auditory dysfunction as a result of opportunistic infections or treatment with drug combination that are potentially toxic.(3) This study was done to know the effect of ART on hearing in HIV positive patients.

During the study period from Jan 2013 to Jan 2015, of the 40 HIV positive patients, males constituted $28(70 \%)$ and females constituted $12(30 \%)$. In our study, the patients were in the age group of 25 to 45 years with a mean age of 32.5 years+/-7.5 years. Transient Evoked Oto-Acoustic Emissions (Screener) was done in all the 40 HIV positive patients up to 6 $\mathrm{KHz}$ at the time of initiation of ART (baseline), $3^{\text {rd }}$ month and $9^{\text {th }}$ month. At the time of initiation of ART (baseline), all the 40 HIV positive patients had normal OAE's. During the $3^{\text {rd }}$ and 9 th month, OAE's in the frequency range from $1500 \mathrm{~Hz}$ to $6000 \mathrm{~Hz}$ were affected in some patients. Hearing assessment using Pure Tone and High Frequency Audiometry up to $12 \mathrm{kHz}$ were done in all the 40 HIV positive patients at the time of initiation of ART (baseline), $3^{\text {rd }}$ month and $9^{\text {th }}$ month. Mean and Standard Deviation were calculated and the p-values were significant in the frequency range from $3000 \mathrm{~Hz}$ to $12000 \mathrm{~Hz}$.

As early as 1987, Sooy reported an abnormal audiologic findings of thresholds more than 25 dBHL with a high frequently sloping configuration on pure tone audiometry in patients with AIDS.(4)

Ultrahigh frequencies up to $12 \mathrm{KHz}$ have also been reported to be finely tuned to the effect of damaging environmental factors such as noise and ototoxic drugs (Campbell, 2007).(5) Our study incorporates ultrahigh frequencies up to $12 \mathrm{KHz}$ and it also incorporates Otoacoustic emissions (OAEs), since OAEs are shown to be sensitive to cochlear damage in ototoxicity monitoring.

Chandrashekar et al, 2000), in concurrence with our study reported that the high frequency of $4000 \mathrm{~Hz}$ and $8000 \mathrm{~Hz}$ were significantly elevated relative to other frequencies. (6)

Sensorineural hearing loss can affect $21 \%$ to $49 \%$ of HIV positive and AIDS subjects, typically causing worse losses for higher frequency perception indicating that there is a need for more studies about auditory pathway injuries caused by HIV.(7) This is also in concurrence with our study.

The management of HIV/AIDS, which involves medications such as Azidothymidine (AZT), has been reported to have adverse effect on the auditory function of individuals infected with HIV/AIDS.(8)

Several cases of ototoxicity have been reported in HIV infected patients treated with zalcitabine (Martinez and French, 1993); didanosine (Colebunders, Dipraetere, Van Wanzeele, and Van Gehuchten, 1998); zidovudine and didanosine (Christensen et al, 1998); stavudine, lamivudine, didanosine and hydroxyurea (Simdon et al, 2001); and post exposure prophylaxis with stavudine, lamivudine and nevirapine (Rey et al, 2002).(9)

While ototoxic hearing loss has been described in HIV infected people after beginning NRTIs, there have been extremely limited prospective studies with one published example of a prospective study by Schouten et al, (2006). In their study, treatment with Zidovudine (ZVD) and Didanosine (DDI) did not result in loss of hearing, even after taking into account noise exposure, immune status and age.(9) This is not in concurrence with our study.
The problem of ototoxic side effects is reported to be more critical in developing countries, where highly effective and low cost drugs are more easily prescribed without adequate monitoring (Arslan et al, 1999).(10)

The known effects of HIV/AIDS on the auditory system that have been reported in the literature are mainly based on cross sectional studies and case reports conducted internationally in industrialized countries with very limited information coming from third world countries where the presentation of the virus and its treatments may be different.(9)

\section{CONCLUSIONS}

1. HIV positive patients had abnormal OAE's in higher frequencies as the duration of ART increases.

2. P-values were significant in higher frequencies with pure tone and high frequency audiometry in HIV positive patients as the duration of ART increases.

\section{LIMITATION OF OUR STUDY}

Though we adopted highly sensitive and specific methods for hearing assessment and since it is a longitudinal study, possible confounders like opportunistic infections and other medications could not be completely accounted for. Further studies involving larger sample size may provide conclusive evidence in this area.

\section{REFERENCES}

1. Rusch M, Nixon S, Schilder A, et al. Impairments, activity limitations and participation restrictions: prevalence and associations among persons living with HIV/ AIDS in British Columbia. Health Quality Life Outcomes 2004;2:46.

2. Friedman JL, Noffsinger D. Hearing loss associated with HIV/AIDS: social, cultural, and political issues. Seminars in Hearing 1998;19:205-14.

3. Jose Zuniga. Communication disorders and HIV disease. International association of physicians in AIDS care. The complete HIV/ AIDS resource. The body Retrieved on $28^{\text {th }}$ Nov, 1999.

http://209.212.93.18/content/treat/art12344.html

4. Sooy CD. The impact of AIDS on otolaryngology-head and neck surgery. Advances in Otolaryngological Head \& Neck Surgery 1987;1:1-28.

5. Campbell KCM. Pharmacology and ototoxicity for audiologists. United States: Thomson Delmar Learning 2007.

6. Chandrashekar SS, Connelly PE, Brahmbhatt SS, et al. Otologic and audiologic evaluation of human immunodeficiency virus infected patients. American Journal of Otolaryngology 2000;21(1):1-9.

7. Roland JT, Alexiades G, Jackman AH, et al. Cochlear implantation in human immunodeficiency virus-infected patients. Otology \& Neurotology 2003;24(6):892-5.

8. Bankaitis AE, Schountz T. HIV related ototoxicity. Seminars in Hearing 1998;19:155-63.

9. Khoza-Shangase Katijah. Is there a need for ototoxicity monitoring in patients with HIV/AIDS? African Journal of Pharmacy and Pharmacology 2010;4(9):574-9.

10. Arslan E, Orzan E, Santarelli R. Global problem of druginduced hearing loss. Annals New York Acad Sci 1999;884:1-14. 